\title{
ANALYSIS OF THE INCREASE OF CONSTRUCTION COSTS IN URBAN REGENERATION PROJECTS
}

\author{
Magdalena Apollo', Emilia Miszewska-Urbańska' \\ 1 Faculty of Civil and Environmental Engineering, Gdansk University of Technology, Narutowicza 11/12 Str., 80- \\ 233 Gdansk, Poland, e-mail: magdalena.apollo@wilis.pg.gda.pl; emilia.miszewska-urbanska@wilis.pg.gda.pl
}

Received: 2015.10.04

Accepted: 2015.11.14

Published: 2015.12.04

\begin{abstract}
The subject of this paper is the analysis and evaluation of the reasons for construction costs increases in urban regeneration projects. The analysis considers major refurbishments of real estates', as well as heavy repair and modernization of the road system. For the period mentioned, the costs from works and expenditure schedules were compared with the costs of additional works, which shows the percentage cost increase in relation to initial project budget assumptions of the case study. The analysis revealed that due to difficulties in assessing technical state of inhabited buildings, the investor and potential contractor should pay special attention to the character of issues presented in this paper, taking into account an increased risk of their occurrence.
\end{abstract}

Keywords: risk analysis, cost management, urban regeneration, cost increase.

\section{INTRODUCTION}

The intervention in the crisis area is usually caused by socio-economic issues, as the urban regeneration takes place within functioning area of the city. Majority of resources is allocated to investment in construction works, which makes the investment risk of urban regeneration dependent specifically on construction works that are a source of widely defined technical risk.

Figure 1 presents the structure of investment of the case study of this paper $-89 \%$ is attributed to major refurbishment of residential and public buildings, as well as reconstruction and modernization of roads and infrastructure. Taking into account a relatively typical investment structure of urban regeneration projects one may theorize that the success of such an endeavor depends not only on achieving social and economic goals, which is currently the main point of consideration, but also on minimizing additional costs. Those are usually created during investment construction works and because of that, taking into account the scale of the investment, they can be crucial in case of complex urban regeneration projects.
Keeping in mind the above, the subject of this paper is the analysis and evaluation of the reasons of construction costs increases in urban regeneration projects. Such analysis should help identify the works with highest risk of potential cost increase; the basis of the research is comparison of values from schedule of works and expenditures with the costs of additional works.

\section{PROJECT ASSUMPTIONS AS BASIS OF THE CASE STUDY}

The analysis of reasons of the cost increase in construction works during urban regeneration project was conducted based on the project "Urban Regeneration of Letnica District in Gdansk", investment part of the project took place in 2010 2012 and social tasks have been planned for the period of eight years (2008-2015). Due to multiaspect degradation of the neighborhood, after a lot of consideration a decision has been made to start urban regeneration project, it was supposed to be a unique chance for both renovation and modernization of the real estate and infrastructure and it also raised hopes of social and economic recovery. 


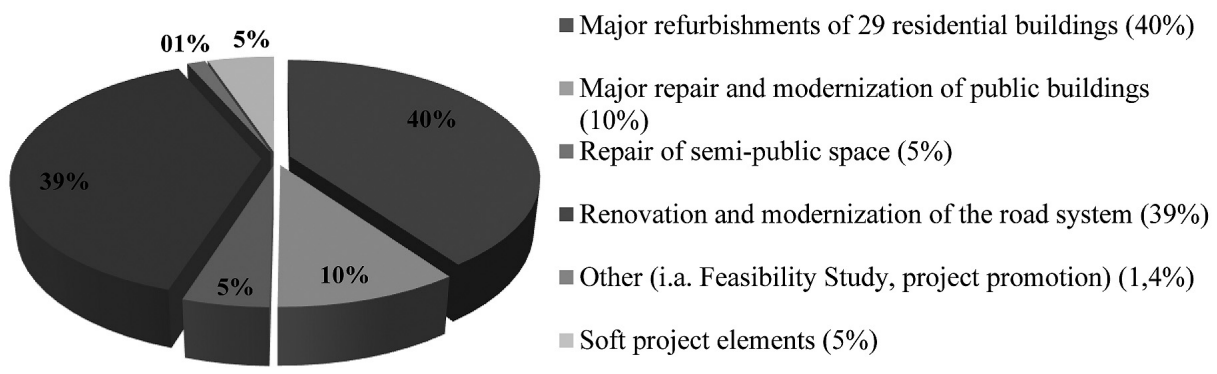

Fig. 1. Breakdown of investment costs for the project "Urban regeneration of Letnica district in Gdansk" (complete value of investment during the project, excluding replacement investments - PLN 71,5 million) [5]

The project of urban regeneration of Letnica included within the scope of investment major refurbishment of 29 residential buildings, adaptation, restoration and reconstruction of public buildings, as well as semi-public spaces and reconstruction and modernization of existing roads and the construction of new ones ${ }^{1}$. Residential buildings that were not qualified for restoration have been demolished and new residential buildings were planned on the recovered land. Noninvestment tasks (social tasks; so called flexibility instrument) included a number of community development projects [1].

Construction works have been completed in stages. Between August 2010 and May 2012 the first stage was completed, and between March 2011 and May 2012 the second stage of refurbishment works has been finished (both the first and the second stage included 15 buildings). Infrastructure works have been divided into three stages, completed between April 2011 and April 2012. Very short investment period, caused by upcoming UEFA European Championship, resulted in overlapping schedules of construction and infrastructure works, which in turn resulted in more and less significant delays to the project. However, it was the cost increase that proved to be more disturbing [2].

This analysis considers major refurbishment of the real estate, including 29 residential buildings and one public building, as well as renovation and modernization of the road system. For the period mentioned the costs from works and expenditure schedules were compared with the costs of additional works, which shows the percentage of cost increase in relation to initial project budget assumptions of the case study.

\footnotetext{
${ }^{1}$ Project to modernize the road system was separated under the name ,Renovation of road system of Letnica district in Gdansk".
}

\section{PROJECT INVESTMENT STRUCTURE}

A complete planned investment cost during the project realization „Urban Regeneration of Letnica District in Gdansk" was PLN 71.578 million. This sum includes qualified costs and flexibility instrument (PLN 70.907 million) as well as unqualified costs of PLN 0.670 million. The entire cost both during project realization and investment implementation was, including replacement investment (PLN 2.989 million), was in total PLN 74.567 million [5].

Renovation and modernization of 29 residential buildings including works on public buildings accounted for $50 \%$ of the cost of the project of Letnica district urban regeneration, which translates into $\sim$ PLN 36 million. This sum includes necessary construction works, as well as technical documentation cost, technical research, investor surveyors and other costs required to complete the project (including conservator's supervision).

All the construction works included in the project „Urban Regeneration of Letnica District in Gdansk" were completed in the traditional system, which means that ,the subject of works is described with design documentation and technical specification regarding completion and approval of works and the value of works is agreed using investor's estimate" [4]. The value of such estimates should be more accurate than the estimates made in the system "design and build", which usually bases calculations only on functional-utility program.

\section{RENOVATION AND MODERNIZATION OF REAL ESTATE}

\section{Analysis of additional costs of stage I}

During the analysis of additional costs it was important and necessary to take into account in- 
creased VAT rates (contracts for additional works have been signed after 2011). In order to eliminate potential material error caused by the change of aforementioned tax rate, only net value of works was compared.

Table 1 presents a list of buildings and information regarding the value of additional works. The research conducted on stage I of the project shows $14.5 \%$ increase of costs, which translates into additional costs of almost PLN 1.7 million net! This significant increase of project costs was caused mainly by additional works conducted in buildings on Starowiejska 14 and Uczniowska 22.

The building at Starowiejska 14 was in worse technical condition that initially assumed. It was necessary to demolish unstable walls and strengthen ceilings among other things. Due to the fact that technical condition was assessed while the building was occupied and its rooms were in various stages of built-up and continuous use, random samples were not sufficient to allow detailed assessment of technical condition.

In the building at Uczniowska 22 a number of additional works was required, including among others:

- bricklaying and plastering of chimney cracks,

- construction and design works related to additional mechanical ventilation that was required,
- design works related to construction documentation, as well as necessary strengthening of foundations,

- piling.

The most significant additional cost (almost PLN 700 000) was the necessary strengthening of foundations, which resulted in a number of additional works expanding the initial scope of the project. In this case again the complete assessment of technical state of the building was only possible after additional samples were taken from the interior and exterior of the building. It was necessary to also conduct geological survey and the assessment of technical condition of bearing walls was only possible after internal plastering was removed.

Different specifics of additional works can be observed in case of buildings located at Starowiejska 28 and 30. In those cases the scope of works was expanded by necessary insulation of external walls made of full brick. Those works were not included in works and expenditure schedule or in construction designs. The interesting thing is that those works could have been easily avoided if the appropriate heat transfer coefficient calculation has been completed in time. Renovated external walls of the buildings did not meet current standards and, as a result, they would probably be prone to freeze-thaw damage, therefore, additional works were deemed necessary.

Table 1. Percentage of costs increase for buildings renovated during stage I of the project [documentation collected from GZNK]

\begin{tabular}{|c|c|c|c|c|}
\hline Id. & Location & Net value of the contract (PLN) & Net value of additional works (PLN) & Cost increase (\%) \\
\hline 1. & Sielska 2 & 485968.00 & 0.00 & 0 \\
\hline 2. & Sielska 4 & 560913.61 & 0.00 & 0 \\
\hline 3. & Sielska 6 & 780055.69 & 95465.36 & 12.2 \\
\hline 4. & Starowiejska 14 & 400384.62 & 133407.99 & 33.3 \\
\hline 5. & Starowiejska 15/16 & 1078739.11 & 96441.96 & 8.9 \\
\hline 6. & Starowiejska 18 & 510649.03 & 42243.30 & 8.3 \\
\hline 7. & Starowiejska 20 & 392771.34 & 0.00 & 0 \\
\hline 8. & Starowiejska 24 & 822469.17 & 0.00 & 0 \\
\hline 9. & Starowiejska 28 & 291846.22 & 60441.43 & 20.7 \\
\hline 10. & Starowiejska 30 & 388794.67 & 39259.26 & 10.1 \\
\hline 11. & Starowiejska 34 & 848074.96 & 143204.38 & 16.9 \\
\hline 12. & Starowiejska 36 & 826576.03 & 0.00 & 0 \\
\hline 13. & Starowiejska 38 & 636087.78 & 0.00 & 0 \\
\hline 14. & Starowiejska 40 & 554305.54 & 0.00 & 0 \\
\hline 15. & Uczniowska 22 & 3096162.44 & 1081567.29 & 34.9 \\
\hline \multirow{2}{*}{\multicolumn{4}{|c|}{$\begin{array}{r}\text { lotal net value of contracts (PLN): } \\
\text { Total net value of additional works }(P L N):\end{array}$}} & 11673798.21 \\
\hline & & & & 1692030.97 \\
\hline \multicolumn{4}{|c|}{ Cost increase in the $i$ stage of the project (\%): } & 14.5 \\
\hline
\end{tabular}


The reasons for additional works in other buildings were:

- significant sagging of wooden ceiling beams requiring their replacement or strengthening as well as significant vertical deviation of walls,

- necessary insulation of foundation walls,

- mould removal works,

Types of construction works, which resulted in the highest unplanned costs increase, are presented in Table 2.

The analysis of available documents (working notes, recommendations of steering committee, change order proposals and others) clearly shows that the assessment of technical state of buildings was difficult and in some cases, for technical reasons, impossible. Taking into account specifics of such investment (major refurbishment of multiple nearly hundred years old buildings) investor and potential contractor should give special consideration to the character of the aforementioned defects, assessing increased risk of their occurrence. Organizational difficulties are not without significance in the context of costs increase. The first stage of renovation works was completed by nine different contractors, which results in numerous issues with coordinating construction works.

\section{Analysis of additional costs of stage II}

Analysis of the costs of stage II also considers net values. Investor's estimates were prepared in third quarter of 2010, but base contracts and contracts for additional works were signed after 2011.

Table 3 presents list of buildings with information regarding the value of their additional works. In the second stage the costs increased by $0.84 \%$, which translates into additional net sum of PLN 84,240.3. Costs increase in this stage was caused by additional works done by contractor number 4 and, what is interesting, it occurred in case of buildings that had lowest tender price for the works in relation to investor's estimates. Again, all additional works in the second stage, in accordance with recommendations to steering committee, were necessary to appropriately complete the basic scope of the project.

At the building at Starowiejska 49 necessary additional works were not foreseen in offer estimates or in technical documents. The building was in worse technical condition than initially assumed, especially construction of chimneys. Parts of window frames and lintels were also in bad technical condition. In the building at Starowiejska 51 the issues were similar, but additional works also had to include the renovation of roof construction that had not been foreseen in estimates. Additional works on the last building involved mainly the façade (integrating colors of gutters, downpipes and metal finishings). All additional works resulted in the need to change the value and schedule of the project (detailed causes of additional works in aforementioned buildings have been presented in Table 4).

Table 2. Ranking of additional works generating costs increase in stage I of the project [documentation collected from GZNK]

\begin{tabular}{|c|c|c|}
\hline Id. & Nature of the works & Cost increase (\%) \\
\hline 1. & $\begin{array}{l}\text { Additional works (excluding construction works), i.a. design works, supervisions, } \\
\text { temporary heating, downtime, geodetic monitoring }\end{array}$ & 4.20 \\
\hline 2. & Earthworks, insulation, foundations (including piling works) & 3.43 \\
\hline 3. & Masonry works (walls, chimneys) & 1.35 \\
\hline 4. & Wooden structure (strengthening or replacing ceiling beams, impregnation) & 1.33 \\
\hline 5. & Thermal insulation & 0.91 \\
\hline 6. & Facade works & 0.75 \\
\hline 7. & Exports of earth and rubble & 0.52 \\
\hline 8. & Strengthening of masonry walls (eg. wall ties) & 0.41 \\
\hline 9. & Partitions and ceilings made of drywall & 0.41 \\
\hline 10. & Painting and plaster coating & 0.34 \\
\hline 11. & Demolition and disassembly works & 0,32 \\
\hline 12. & Reinforced concrete frame (including lintels, bond beams) & 0.17 \\
\hline 13. & Electrical installations & 0.14 \\
\hline 14. & Other & 0.22 \\
\hline & Total cost increase in the $i$ stage of the project: & 14.49 \\
\hline
\end{tabular}


Table 3. Percentage of costs increase for buildings renovated during stage II of the project [documentation collected from GZNK]

\begin{tabular}{|c|c|c|c|c|c|}
\hline Id. & Contractor & Location & $\begin{array}{l}\text { Net value of the contract } \\
(\text { PLN) }\end{array}$ & $\begin{array}{c}\text { Net value of additional works } \\
\text { (PLN) }\end{array}$ & $\begin{array}{c}\text { Cost increase } \\
(\%)\end{array}$ \\
\hline 1. & \multirow{3}{*}{1} & Starowiejska 23 & 551473.68 & 0.00 & 0 \\
\hline 2. & & Starowiejska 25 & 565111.33 & 0.00 & 0 \\
\hline 3. & & Starowiejska 27 & 572377.27 & 0.00 & 0 \\
\hline 4. & \multirow{5}{*}{2} & Starowiejska 29 & 566360.10 & 0.00 & 0 \\
\hline 5. & & Starowiejska 31 & 585550.44 & 0.00 & 0 \\
\hline 6. & & Starowiejska 35 & 599814.12 & 0.00 & 0 \\
\hline 7. & & Starowiejska 37 & 623019.73 & 0.00 & 0 \\
\hline 8. & & Starowiejska 39 & 929348.48 & 0.00 & 0 \\
\hline 9. & \multirow{4}{*}{3} & Starowiejska 41 & 1157054.35 & 0.00 & 0 \\
\hline 10. & & Starowiejska 43 & 1184574.53 & 0.00 & 0 \\
\hline 11. & & Starowiejska 45 & 649920.72 & 0.00 & 0 \\
\hline 12. & & Starowiejska 47 & 656341.39 & 0.00 & 0 \\
\hline 13. & \multirow{3}{*}{4} & Starowiejska 49 & 409675.31 & 44561.97 & 10.88 \\
\hline 14. & & Starowiejska 51 & 462177.65 & 26897.65 & 5.82 \\
\hline 15. & & Starowiejska 53 & 458962.14 & 12780.69 & 2.78 \\
\hline & & \multicolumn{2}{|c|}{ Total net value of contracts (PLN): } & \multicolumn{2}{|l|}{9971761.24} \\
\hline & & \multicolumn{2}{|c|}{ Total net value of additional works (PLN): } & \multicolumn{2}{|l|}{84240.31} \\
\hline & & \multicolumn{2}{|c|}{ Cost increase in the $i$ stage of the project (\%): } & \multicolumn{2}{|l|}{0.84} \\
\hline
\end{tabular}

Table 4. Ranking of additional works generating costs increase in stage II of the project [documentation collected from GZNK]

\begin{tabular}{|c|l|c|}
\hline Id. & \multicolumn{1}{|c|}{ Nature of the works } & Cost increase (\%) \\
\hline 1. & Roof-construction and flashings & 0.27 \\
\hline 2. & Facade works including plaster coating & 0.21 \\
\hline 3. & Masonry works (walls, chimneys) & 0.16 \\
\hline 4. & Thermal insulation & 0.09 \\
\hline 5. & Reinforced concrete frame (foundations, internal stairs, lintelsa) & 0.06 \\
\hline 6. & Other & 0.05 \\
\hline & Total cost increase in the $i$ stage of the project: & 0.84 \\
\hline
\end{tabular}

The analysis of additional costs of stage II leads to similar conclusions as in stage I. Assessment of technical state of each building or specific construction elements was difficult and in some cases impossible for a variety of reasons. It was observed that the scope of additional works has been smaller resulting in lower costs. Also selection of contractors has been different than in stage I. Due to organization problems in the first stage, caused by too high number of contractors, in the second stage it was decided to call for tenders for major refurbishment of groups of buildings. This results in selecting four contractors, three of whom worked already in stage I. One san assume that experience gathered during earlier works allowed for more realistic cost estimation in stage II and no need additional works, and the required works resulted in relatively low cost increase.

\section{RENOVATION OF ROAD SYSTEM IN LETNICA DISTRICT OF GDANSK}

Project of renovation of road system in Letnica included renovation, construction and modernization of streets of length of $\sim 1.5 \mathrm{~km}$.

Similarly to construction works in the buildings, road works were divided into stages. Initial three-stage division was assumed by the designer and was aimed at making organization of works easier. In the end, due to the need to coordinate works of all contractors (real estate and infrastructure) all stages were worked on in parallel. Such organization resulted in overlap of works schedules of building works and infrastructure works. Contractor responsible for road works was forced to stop the works temporarily and adjust the schedule to the schedules of external contrac- 
tors (including contractors working on buildings renovation and constructing new buildings - TBS "Motława" and GTBS). Change in works schedule was also caused by a number of collisions with utility networks that were not on provided inventories and maps, as well as by delays in making the lane on the side of renovated buildings available [6].

\section{ANALYSIS OF ADDITIONAL COSTS OF ROAD SYSTEM}

According to initial estimates, renovation and modernization of streets together with renovation of infrastructure accounted for 39\% of costs of the entire project of Letnica urban regeneration, which translates into $\sim$ PLN 27.5 million. This includes necessary construction works, as well as costs of technical documentation, investor's surveyor and other costs necessary for project completion (sappers' supervision among others).

Two contractors were responsible for road works, Pol-Dróg Gdańsk Sp. z o.o. and WPRD Gravel Sp. z o.o., however, due to the availability of data the below analysis only considers the first of them. Total value of contracts is estimated at PLN 15.5 million [3]. Percentage share of costs of specific infrastructure works covered in the contract with Pol-Dróg Gdańsk Sp. z o.o. is presented in Table 5.

Consequences of issues occurring during road works were not as serious as in case of buildings. Despite overlapping schedules there was no significant delay in completing works and costs increase was relatively low in comparison to increase noted during building construction and renovation works.

Types of works where unplanned increase was noticed are presented in Table 6 . The analysis considers gross values, as both the base contract and contracts for additional works were signed after 2011 (at the same VAT rate).

As a result of conducted research it was established that increase of costs of the project „Renovation of Road System of Letnica District in Gdansk" was equal to $0.66 \%$, which translates into additional gross sum of PLN 57 500. Cost increase was mainly caused by additional works required on water supply network, as well as the necessity of putting reinforced concrete plates on heating ducts to bear the load.

The reasons for additional works, apart from accessory buildings, included, among others, the already mentioned collisions of works with existing utility networks that were not shown in the maps.

Table 5. Percentage share of costs of renovation and modernization works according to contract [documentation collected from Pol-Dróg Gdańsk Sp. z o.o.]

\begin{tabular}{|c|l|c|}
\hline Id. & \multicolumn{1}{|c|}{ Nature of the works } & Share of costs (\%) \\
\hline 1. & Roadworks & 39.0 \\
\hline 2. & Repair of storm water drainage & 24.8 \\
\hline 3. & Reconstruction of water supply network & 10.3 \\
\hline 4. & Structural landscaping & 6.0 \\
\hline 5. & Reconstruction of the telecommunication network & 4.3 \\
\hline 6. & Reconstruction of heating network (including engineering structures) & 3.2 \\
\hline 7. & Greenery and maintenance of greenery & 2.7 \\
\hline 8. & Street lighting & 2.6 \\
\hline 9. & Traffic arangement & 2.5 \\
\hline 10. & $\begin{array}{l}\text { Other (including reconstruction of power transmission systems, sanitary networks, } \\
\text { utility connections, UXO monitoring) }\end{array}$ & 4.7 \\
\hline \multicolumn{2}{|}{ The gross value of the contract (PLN): 8 674 788.93 } \\
\hline
\end{tabular}

Table 6. Ranking of additional works generating costs increase in the urban regeneration of road system [documentation collected from Pol-Dróg Gdańsk Sp. z o.o.]

\begin{tabular}{|c|l|c|}
\hline Id. & \multicolumn{1}{|c|}{ Nature of the works } & Cost increase (\%) \\
\hline 1. & Reconstruction of the water supply system (including utility connections) & 0.26 \\
\hline 2. & Reconstruction of heating network with heat network engineering structures & 0.22 \\
\hline 3. & Structural landscaping Cost increase within urban regeneration of road system: & 0.19 \\
\hline \multicolumn{2}{r}{ Con } \\
\hline
\end{tabular}




\section{CONCLUSIONS}

In the first and second stage of the project the cost increase amounted to PLN 2 million gross, which constitutes $8 \%$ of the value of basic contracts. Renovation and modernization of road system resulted in cost increase of PLN 57500 gross, which constitutes almost $0.66 \%$ of road works contract value. Assuming that both stages of building construction works $(50 \%)$ and road system works (39\%) amounted to $89 \%$ of the investment of the entire project "Urban Regeneration of Letnica District in Gdansk", they generated cost increase of $4.5 \%$.

Analysis of additional costs of first and second stage of works on buildings results in similar conclusions. Due to difficulties in assessing technical state of inhabited buildings, the investor and potential contractor should pay special attention to character of issues that occurred presented in this paper, taking into account increased risk of their occurrence.

The factors affecting the increase of costs in the project (in relation to investor's and contractor's estimates and contract based on them) include, other than specific construction works [4]:

- underestimating the value of works (too low quantities of unit prices),

- incomplete or inaccurate tender documentation,

- introduction of replacement works or optimization of materials and/or technology

Wide scope of renovation and modernization works both in the buildings and widely defined infrastructure, justifies limiting the number of contractors cooperating on the construction site. Delays in completing works resulting in costs increase are often caused by issues with coordinating works.

\section{REFERENCES}

1. Apollo M.: Wpływ czynników społecznych i ekonomiczno-gospodarczych na skuteczność procesów rewitalizacji urbanistycznej. W: Nowe trendy w naukach inżynieryjnych, 4 . Monografia. Gdańsk 2013.

2. Apollo M., Miszewska-Urbańska E., Wiśniewski R.: Problemy własnościowe nieruchomości na terenach rewitalizowanych. W: Współczesne uwarunkowania gospodarowania przestrzenią - szanse i zagrożenia dla zrównoważonego rozwoju. Tom $\mathrm{V}$. Organizacja gospodarowania przestrzenią. Monografia. Oficyna Wydawnicza Politechniki Warszawskiej. Warszawa 2014.

3. Letnica wczoraj i dziś. Broszura wydana przez Urząd Miasta Gdańsk. Gdańsk 2012.

4. Leśniak A., Plebankiewicz E., Zima K.: Wpływ założeń kalkulacyjnych na wynik oszacowania kosztów robót budowlanych. Czasopismo Techniczne, nr 3-B, 2012.

5. Studium wykonalności dla projektu ,Rewitalizacja Letnicy w Gdańsku”, Załącznik nr 1 do wniosku o dofinansowanie w ramach poddziałania 3.2.1 Kompleksowe Przedsięwzięcia Rewitalizacyjne Regionalnego Programu Operacyjnego dla Województwa Pomorskiego na lata 2007-2013. Gdańsk, 2009.

6. Uchwała Nr XXIII/445/12 Rady Miasta Gdańska z dnia 23 lutego 2012 roku zmieniająca uchwałę w sprawie przyjęcia Wieloletniej Prognozy Finansowej Gminy Miasta Gdańska na lata 2012-2040. 